\title{
Outcomes in hypertensive disorders of pregnancy in the North Indian population
}

This article was published in the following Dove Press journal:

International Journal of Women's Health

5 March 2013

Number of times this article has been viewed

\author{
Rekha Sachan' \\ Munna Lal Patel ${ }^{2}$ \\ Pushpalata Sachan ${ }^{3}$ \\ Amrita Gaurav' \\ Meenakshi Singh' \\ Bhumika Bansal' \\ 'Department of Obstetrics and \\ Gynecology, ${ }^{2}$ Department of Medicine, \\ ${ }^{3}$ Department of Physiology, King \\ George's Medical University, Lucknow, \\ Uttar Pradesh, India
}

\begin{abstract}
Introduction: Hypertensive disorders complicating pregnancy seriously endanger the safety of the mother and fetus during pregnancy. Very few studies have explored hypertensive disorders of pregnancy in India, even though this disease has been associated with adverse maternal and perinatal outcomes. This study aimed to analyze the disease pattern and risk factors associated with the disorder and assess the maternal and fetal outcomes in cases of hypertensive disorders of pregnancy.
\end{abstract}

Subjects and methods: This case-control study was carried out over 1 year from 2011 to 2012 at the Department of Obstetrics and Gynecology, King George's Medical University, Lucknow, Uttar Pradesh, India. A total of 149 patients were enrolled in the study. As seven were lost to follow-up, analysis was carried out on 142 cases. Patients were further classified according to the National High Blood Pressure Education Program Working Group (2000) as having mild preeclampsia (65 cases), severe preeclampsia (32 cases), or eclampsia (45 cases). Thirty-one healthy pregnant non-hypertensive women were enrolled into the study as controls.

Results: The most common manifestation was edema, seen in $90 \%$ of cases. Proteinuria was also relatively common, $26.76 \%$ of patients with proteinuria of $\geq 300 \mathrm{mg} / 24$ hours, $47.88 \%$ with proteinuria of $\geq 2 \mathrm{~g} / 24$ hours, and $25.35 \%$ with a urinary protein excretion of $3-5 \mathrm{~g} / 24$ hours. Central nervous system involvement was observed in $42.2 \%$ of cases, elevated bilirubin levels in $47.0 \%$, visual symptoms in $6.4 \%$, vaginal bleeding in $11.3 \%$, and HELLP (hemolysis, elevated liver enzymes, and low platelet count) syndrome was reported in $2.80 \%$. Maternal deaths occurred in $2.8 \%$ of cases, all of which were from the eclampsia group. Stillbirths occurred in $16.9 \%$ of cases, and overall neonatal death observed in $4.23 \%$ of cases.

Conclusion: Women with hypertensive disorders of pregnancy were more prone to adverse maternal and fetal outcomes than normotensive pregnant women, but we observed a decreasing trend in the present study compared with that reported in other studies, which might be due to the increased number of hospital deliveries that occurred in our study.

Keywords: HELLP syndrome, acute renal failure, maternal outcome, neonatal outcome

\section{Introduction}

Hypertensive disorders complicating pregnancy (HDP) is the most common complication in pregnancy. The incidence varies in different populations and is affected by the definition used. HDP is influenced by nulliparity, age, and race. In India in 2006, the incidence of HDP was 5.38\%, while preeclampsia, eclampsia, and HELLP (hemolysis, elevated liver enzymes, and low platelet count) syndrome accounted for $44 \%, 40 \%$, and $7 \%$ of complications, respectively. ${ }^{1}$ Maternal and perinatal deaths have been reported in $5.5 \%$ and $37.5 \%$ of deliveries, respectively. ${ }^{1}$ HDP comprises preeclampsia and eclampsia.
Correspondence: Rekha Sachan Department of Obstetrics and Gynecology, King George's Medical University, Lucknow, Uttar Pradesh, India Tel +9l 8765000700

Email drrekhasachan@gmail.com 
The former is a multisystem disorder of unknown etiology that affects $4 \%-5 \%$ of pregnancies ${ }^{2,3}$ whereas the latter is the occurrence of seizures in women with preeclampsia. The incidence of eclampsia is $0.3 \%-0.9 \%$ and it has a maternal mortality rate of $0.5 \%-10.0 \%{ }^{4}$

The pathogenesis of HDP is not completely clear. It is a multifactorial disease and its central pathogenesis seems to involve the systemic activation and injury of maternal endothelial cells, which manifests as raised blood pressure (BP), proteinuria, systemic inflammatory response, and accumulation of antiangiogenic factors, which seem to cause the disease by depriving the glomerular endothelial cells of essential growth factors. Pregnancy termination reverses the clinical manifestations of the disease, suggesting that trophoblastic invasion has a central role in the pathogenesis of preeclampsia. ${ }^{5}$ A recent study revealed that excessive placental secretion of soluble fms-like tyrosine kinase-1 may contribute to endothelial dysfunction, hypertension, and proteinuria in preeclampsia. ${ }^{5}$ In a multicenter study, approximately $30 \%$ of HDP cases were due to chronic hypertension, while $70 \%$ were due to gestational hypertension/preeclampsia. ${ }^{6}$

Very few studies have explored hypertensive disorders of pregnancy in India, even though these disorders have been associated with adverse maternal and perinatal outcomes. ${ }^{7}$ The aim of the study reported here was to analyze the disease pattern and risk factors associated with the disorder and to assess the maternal and fetal outcomes in cases of HDP.

\section{Subjects and methods}

This prospective case-control study was carried out over 1 year from 2011 to 2012 at the Department of Obstetrics and Gynecology, King George's Medical University, Lucknow, Uttar Pradesh, India. Ethical clearance was obtained from the institutional ethics committee of the university. A total of 1850 pregnant women who signed informed consent forms were screened over the year, 149 of whom were diagnosed with HDP and enrolled in our study; seven were subsequently lost to follow-up. Analysis was therefore carried out on 142 cases. Patients were categorized according to the National High Blood Pressure Education Program Working Group ${ }^{8}$ definitions as having mild preeclampsia (65 cases), severe preeclampsia (32 cases), or eclampsia (45 cases). The women enrolled had a gestational age of 20-40 weeks. Thirty-one healthy pregnant non-hypertensive women were also enrolled into the study as controls.

BP was measured using a mercury sphygmomanometer every 4 hours in patients with mild preeclampsia and severe preeclampsia and every hour in patients with eclampsia, with the procedure undertaken on the patient's right arm while in a supine position. Korotkoff sounds were monitored to measure diastolic BP. Assessment of edema was done clinically on general examination by applying thumb pressure over the medial malleolus. Fundus examination of the eye was performed by direct ophthalmoscopy and any hypertensive retinal changes (papillae edema, exudates, hemorrhages, and blurring of disc) were noted.

"Mild preeclampsia" was defined as BP $\geq 140 / 90 \mathrm{mmHg}$ but $<160 / 110 \mathrm{mmHg}$ with proteinuria $\geq 300 \mathrm{mg} / 24$ hours. "Severe preeclampsia" was defined as BP $\geq 160 / 110 \mathrm{mmHg}$ with urinary protein excretion of $\geq 2.0 \mathrm{~g} / 24$ hours or any of oliguria ( $<400 \mathrm{~mL}$ urine/24 hours), visual disturbance, serum creatinine $\geq 1.2 \mathrm{mg} / \mathrm{dL}$, platelet count of $<1 \mathrm{lacs} / \mu \mathrm{L}$, microangiopathic hemolysis (increased lactate dehydrogenase [LDH], elevated serum alkaline phosphatase). "Eclampsia" was defined as occurrence of new-onset grand mal seizure in a patient with preeclampsia. "HELLP syndrome" was defined as liver enzyme elevation (aspartate transaminase $>70 \mathrm{IU} / \mathrm{L}$ ), hemolysis $(\mathrm{LDH}>600 \mathrm{IU} / \mathrm{L})$, and low platelet count $\left(\leq 100,000 / \mathrm{mm}^{3}\right)$.

"Acute renal failure" was defined as elevated creatinine $(\geq 1.5 \mathrm{mg} / \mathrm{dL}$ ) or oliguria of 24-hour or longer duration. "Proteinuria" was defined as urinary protein excretion of $\geq 300 \mathrm{mg} / 24$ hours. "Nephrotic syndrome" was defined as urinary protein excretion of $\geq 3.5 \mathrm{~g} / 1.73 \mathrm{~m}^{2} /$ day, associated with distinct lowering of serum albumin (ie, $\leq 2.5 \mathrm{~g} / \mathrm{dL}$ ). "Pregnancy-induced hypertension" was defined as BP $\geq 140 / 90 \mathrm{mmHg}$ on two occasions at least 6 hours apart in women who were normotensive in the pre-pregnancy phase. "Hyperuricemia" was defined as elevated uric acid level (ie, $\geq 4.5 \mathrm{mg} / \mathrm{dL}$ ). Investigations of these were carried out in an accredited laboratory. Serum creatinine was measured using the Jaffe's method, the sulfosalicylic acid test was utilized for urinary protein estimation, and uric acid estimation was determined by nephelometry.

Patients with preexisting renal disease, hypertension, diabetes mellitus, gestational hypertension, active urinary tract infection, or who refused to cooperate with the study were excluded.

Data were collected and analyzed. Demographic characteristics, gestational age, BP on admission, biochemical parameters (including complete hematology, biochemistry, 24-hour urinary protein), ultrasonography of abdomen complications during hospital stay, and maternal and fetal outcome were recorded. The renal manifestations (proteinuria, hyperuricemia, and acute renal failure) were 
recorded for individual patients. BP and labor were strictly monitored. All patients were given antihypertensive drugs however, in mild preeclampsia cases, the patients were provided Methyldopa and in severe preeclampsia, the patients were given Labetalol. Methyldopa is a centrally acting US Food and Drug Administration category B drug considered safe for the mother and fetus. Labetalol, a Food and Drug Administration category $\mathrm{C}$ drug, was given in cases of severe preeclampsia and eclampsia. Magnesium sulfate, according to the Pritchard regimen, was administered to control convulsions in patients with eclampsia, along with fluid replacement; in addition, patients with eclampsia were intensively monitored. All patients were followed-up for 12-weeks postpartum.

\section{Statistical analysis}

Data were analyzed using Stata software (v 11.2; Statacorp, College Station, TX, USA). The categorical data are presented as $\mathrm{n}(\%)$, whereas continuous variables as mean \pm standard deviation. The associations between two or more categorical variables were tested using the chi-square test with appropriate correction. If the data were normally distributed, the two-sample $t$-test was used to determine the differences between the mean of two different groups; otherwise, the Mann-Whitney U test was used to test the level of significance between two values. One-way analysis of variance was used to test the difference between more than two groups and the Kruskal-Wallis test was used if the data were not normally distributed. Bonferroni correction was applied. A difference between two values was considered significant if $P \leq 0.05$.

\section{Results}

Analysis was carried out on data for 142 patients. There were 65 cases of mild preeclampsia (45.8\%), 32 cases of severe preeclampsia $(22.5 \%)$, and 45 cases of eclampsia $(31.7 \%)$. Table 1 shows that the majority of patients were in the 25-35 years age group; 50 patients in this age group had preeclampsia, 19 severe preeclampsia, and 26 eclampsia.

The majority of control patients $(87.10 \%)$ were of middle socioeconomic status. Most of the patients with mild preeclampsia (67.69\%) and severe preeclampsia (71.88\%) were of middle socioeconomic status, whereas the majority of patients in the eclampsia group (73.33\%) were of low socioeconomic status (based on Kuppuswamy's socioeconomic status scale, updated in 2012). ${ }^{9}$

Just over half of the patients $(53.52 \%)$ were primigravida, while the remainder $(46.48 \%)$ was multigravida. In the control group, 41.94\% subjects were primigravida. Two patients in the mild preeclampsia group had a history of similar disease in the past: one had a history of antepartum eclampsia and the other a history of preeclampsia. One patient in the severe preeclampsia group had a history of preeclampsia in a previous pregnancy.

Mean systolic BP was $117.84 \mathrm{mmHg}$ in the control group, $145.32 \pm 9.7 \mathrm{mmHg}$ in the mild preeclampsia group, $159.88 \pm 8.3 \mathrm{mmHg}$ in the severe preeclampsia group, and $156.89 \pm 9.5 \mathrm{mmHg}$, in the eclampsia group. The difference was statistically significant between the study and control groups $(P<0.0001)$. Similarly, mean diastolic BP was $77.42 \pm 6.8 \mathrm{mmHg}$ in the control group, $93.72 \pm 5.2 \mathrm{mmHg}$ in the mild preeclampsia group, $103.25 \pm 7.6 \mathrm{mmHg}$ in the severe preeclampsia group, and $101.20 \pm 7.9 \mathrm{mmHg}$ in the eclampsia group. The difference was statistically significant between the study and control groups $(P<0.0001)$. Oliguria was found in $18.75 \%$ of severe preeclampsia cases and $20.00 \%$ of eclampsia cases $(P=0.001)$ (Table 1$)$.

The most common manifestation was edema, which was seen in $90 \%$ of patients. In our study proteinuria $\geq 300 \mathrm{mg} / 24$ hours was seen in $26.76 \%$ of cases and of $\geq 2 \mathrm{~g} / 24$ hours was seen in $47.88 \%$ of cases. Slightly more than one-quarter of cases $(25.35 \%)$ had urinary protein excretion of $3-5 \mathrm{~g} / 24$ hours. There was central nervous system involvement in $42.2 \%$ of cases, elevated bilirubin level in $57.0 \%$, visual symptoms in $6.4 \%$, vaginal bleeding in $11.3 \%$, and HELLP syndrome in $2.8 \%$ (Table 2 ).

Biochemical investigation revealed significant differences in the levels of all parameters between the study and control groups (Table 3 ).

Most maternal complications were found in the severe preeclampsia group, followed by in the eclampsia and mild preeclampsia groups. There were four maternal deaths, all in patients in the eclampsia group, comprising $8.89 \%$ of that group (Table 4). The overall maternal mortality rate was $2.8 \%$ of all study cases. One patient (3.13\%) had acute renal failure in the severe preeclampsia group and placental abruption was reported in $15.38 \%$ cases of preeclampsia, $25.00 \%$ cases of severe preeclampsia, and $15.56 \%$ of eclampsia (Table 4 ).

The adverse neonatal events that occurred in the various study groups and controls are shown in Tables 5 and 6. Most of the babies requiring resuscitation were born to patients with severe preeclampsia $(40.75 \%)$, followed by to those with eclampsia (38.70\%), mild preeclampsia (18.40\%), and controls $(6.50 \%)$.

During hospital admission, $16.90 \%$ of babies were stillborn, $7.69 \%$ of whom were born to patients with mild 
Table I Demographic profile

\begin{tabular}{|c|c|c|c|c|c|}
\hline Group & $\begin{array}{l}\text { Control } \\
(n=3 I)\end{array}$ & $\begin{array}{l}\text { Mild } \\
\text { preeclampsia } \\
(n=65)\end{array}$ & $\begin{array}{l}\text { Severe } \\
\text { preeclampsia } \\
(n=32)\end{array}$ & $\begin{array}{l}\text { Eclampsia } \\
(n=45)\end{array}$ & $P$ value \\
\hline \multicolumn{6}{|l|}{ Age group, \% (n) } \\
\hline$<25$ years & $29.03(9)$ & $23.08(15)$ & $37.50(12)$ & $42.22(19)$ & 0.136 \\
\hline $25-35$ years & $70.97(22)$ & $76.92(50)$ & $59.38(19)$ & $57.78(26)$ & \\
\hline$>35$ years & $0.00(0)$ & $0.00(0)$ & $3.13(1)$ & $0.00(0)$ & \\
\hline \multicolumn{6}{|l|}{ Gravida, \% (n) } \\
\hline $0-1$ & $41.94(13)$ & $50.77(33)$ & $53.13(17)$ & $57.78(26)$ & 0.548 \\
\hline $1-2$ & $32.26(10)$ & $26.13(17)$ & $18.75(6)$ & $24.44(\mathrm{II})$ & \\
\hline $2-3$ & $16.13(5)$ & $13.85(9)$ & $12.50(4)$ & II.II (5) & \\
\hline $3-4$ & $6.45(2)$ & $1.54(I)$ & $9.38(3)$ & $2.22(I)$ & \\
\hline $4-5$ & $3.23(1)$ & $6.15(4)$ & $0.00(0)$ & $4.44(2)$ & \\
\hline $5-6$ & $0.00(0)$ & $1.54(1)$ & $6.25(2)$ & $0.00(0)$ & \\
\hline \multicolumn{6}{|c|}{ Socioeconomic status, \% (n) } \\
\hline Low & $12.90(4)$ & $32.31(2 I)$ & $28.13(9)$ & $73.33(33)$ & 0.0001 \\
\hline Medium & $87.10(27)$ & $67.69(44)$ & $71.88(23)$ & $26.67(12)$ & \\
\hline \multicolumn{6}{|c|}{ History of hypertensive disease } \\
\hline \multicolumn{6}{|c|}{ in pregnancy, \% (n) } \\
\hline Not present & $100.00(31)$ & $96.92(63)$ & $96.88(3 \mathrm{I})$ & $100.00(45)$ & \\
\hline Present & $0.00(0)$ & $3.08(2)$ & $3.13(1)$ & $0.00(0)$ & \\
\hline \multicolumn{6}{|l|}{ CNS, \% (n) } \\
\hline Normal & 100.00 & $100.00(65)$ & 100.00 & $57.78(26)$ & 0.000 \\
\hline Abnormal & $0.00(0)$ & $0.00(0)$ & $0.00(0)$ & $42.22(19)$ & \\
\hline \multicolumn{6}{|l|}{ Hypertension, $\mathrm{mmHg}$} \\
\hline Mean SBP & $117.84 \pm 4.7$ & $145.32 \pm 9.7$ & $159.88 \pm 8.3$ & $156.89 \pm 9.50$ & $<0.000$ I \\
\hline Mean DBP & $77.42 \pm 6.8$ & $93.72 \pm 5.2$ & $103.25 \pm 7.6$ & $101.20 \pm 7.90$ & $<0.000$ I \\
\hline \multicolumn{6}{|l|}{ Urine output, \% (n) } \\
\hline$<400 \mathrm{~mL} / 24$ hours & $0.00(0)$ & $0.00(0)$ & $18.75(6)$ & $20.00(9)$ & 0.001 \\
\hline$>400 \mathrm{~mL} / 24$ hours & $100.00(31)$ & $100.00(65)$ & $81.25(26)$ & $80.00(36)$ & \\
\hline
\end{tabular}

Note: The difference between two values was considered significant if $P<0.05$.

Abbreviations: CNS, central nervous system; DBP, diastolic blood pressure; SBP, systolic blood pressure.

preeclampsia, $15.60 \%$ to patients with severe preeclampsia, and $31.10 \%$ to patients with eclampsia.

Most normal deliveries occurred in the preeclampsia group (61.54\%), whereas most cesarean sections were undertaken in patients in the severe preeclampsia group (43.75\%). In the severe preeclampsia group, most babies were born with a birth weight between 1500 and $2490 \mathrm{~g}$ (87.5\%), whereas,

Table 2 Clinical manifestations of hypertensive disorders of pregnancy at presentation $(n=142)$

\begin{tabular}{lll}
\hline Clinical features & Patients, $\mathbf{n}$ & $\%$ \\
\hline Hypertension & 142 & 100.00 \\
Edema & 128 & 90.00 \\
Proteinuria & & \\
$\quad \geq 300 \mathrm{mg} / \mathrm{dL}$ & 38 & 26.76 \\
$\quad \geq 2 \mathrm{~g} / \mathrm{dL}$ & 68 & 47.88 \\
$\quad 3-5 \mathrm{~g} / \mathrm{dL}$ & 36 & 25.35 \\
Central nervous system & 19 & 42.20 \\
Jaundice & 81 & 57.00 \\
Visual symptoms & 9 & 6.40 \\
Vaginal bleeding & 16 & 11.30 \\
HELLP syndrome & 4 & 2.80 \\
\hline
\end{tabular}

Abbreviation: HELLP, hemolysis, elevated liver enzymes, and low platelet count. in the eclampsia group, most babies $(66.7 \%)$ were born with a birth weight $>2500 \mathrm{~g}$ (Table 5).

In the HDP groups, $16.90 \%$ of babies were born with an Apgar score $<7$ compared with $6.45 \%$ of babies in the control group. Further, $28.8 \%$ of neonates born to women in the hypertensive disorders groups required resuscitation and $20.3 \%$ required hospital admission, whereas only $6.5 \%$ of neonates born to women in the control group required resuscitation and/or hospital admission. The overall neonatal mortality rate was $4.23 \%$. Most neonatal deaths occurred in the eclampsia group (9.7\%; Table 6).

\section{Discussion}

Analysis was carried out on 142 cases (65 mild preeclampsia cases, 32 severe preeclampsia cases, and 45 eclampsia cases) and 31 controls. Upon screening 1850 pregnant women, hypertensive disorders of pregnancy were found in $8.05 \%$. HDP has been reported in $6 \%-8 \%$ of pregnancies and may affect as many as $20 \%$ of pregnancies. $^{8}$ Similarly, in an Indian study, the incidence of preeclampsia was reported to be $7 \%-9 \%{ }^{10}$ Prakash et al reported preeclampsia in $5.8 \%$ 
Table 3 Biochemical parameters

\begin{tabular}{|c|c|c|c|c|c|}
\hline Investigation & $\begin{array}{l}\text { Control } \\
(n=31)\end{array}$ & $\begin{array}{l}\text { Mild preeclampsia } \\
(n=65)\end{array}$ & $\begin{array}{l}\text { Severe preeclampsia } \\
(n=32)\end{array}$ & $\begin{array}{l}\text { Eclampsia } \\
(n=45)\end{array}$ & $P$ value \\
\hline Hemoglobin $(g / d L)$ & $10.81 \pm 0.5$ & $9.58 \pm 1.4$ & $9.71 \pm 1.2$ & $9.24 \pm 1.0$ & 0.0059 \\
\hline Platelet count (lac/mm $)$ & $2.10 \pm 0.3$ & $1.64 \pm 0.4$ & $1.59 \pm 0.4$ & $1.65 \pm 0.4$ & $<0.001$ \\
\hline Serum urea $(\mathrm{mg} / \mathrm{dL})$ & $20.03 \pm 4.1$ & $30.05 \pm 9.7$ & $38.72 \pm 9.7$ & $32.08 \pm 75$ & $<0.001$ \\
\hline Serum creatinine $\mathrm{mg} / \mathrm{dL}$ & $0.60 \pm 0.2$ & $1.27 \pm 0.5$ & $2.67 \pm 1.3$ & $1.95 \pm 0.7$ & $<0.001$ \\
\hline Serum bilirubin (mg/dL) & $0.49 \pm 0.3$ & $\mathrm{I} .3 \mathrm{I} \pm 0.8$ & $1.89 \pm 1.2$ & $1.86 \pm 0.8$ & $<0.001$ \\
\hline Serum ALP (IU/L) & $61.84 \pm 9.3$ & $359.40 \pm 164.5$ & $337.34 \pm 188$ & $443.60 \pm 168.1$ & $<0.001$ \\
\hline Serum GPT (IU/L) & $47.77 \pm 13.8$ & $215.94 \pm 125.8$ & $257.72 \pm 174.1$ & $354.89 \pm 193.2$ & $<0.001$ \\
\hline Serum GOT (IU/L) & $49.71 \pm 4.4$ & $208.57 \pm 130.9$ & $299.00 \pm 167.8$ & $338.09 \pm 173.1$ & $<0.001$ \\
\hline Serum uric acid (mg/dL) & $2.24 \pm 0.5$ & $7.36 \pm 1.8$ & $8.36 \pm 1.8$ & $6.61 \pm 2.0$ & $<0.001$ \\
\hline Serum LDH (IU/L) & $186.48 \pm 41.9$ & $735.75 \pm 268.5$ & $959.13 \pm 238.2$ & $868.67 \pm 247.7$ & $<0.001$ \\
\hline
\end{tabular}

Note: The difference between two values was considered significant if $P<0.05$.

Abbreviations: ALP, alkaline phosphatase; GOT, glutamic oxaloacetic transaminase; GPT, glutamate pyruvate transaminase; LDH, lactate dehydrogenase.

of pregnant women. ${ }^{11}$ In the present study, of the 142 cases, $45.8 \%$ had mild preeclampsia, $22.5 \%$ had severe preeclampsia, and $31.7 \%$ had eclampsia.

Young age and first pregnancy are known risk factors for the development of preeclampsia. In this study, the ages of study group subjects were similar to those of controls. The mean age of control subjects was $27.19 \pm 3.3$ years, $26.28 \pm 2.7$ years for those with mild preeclampsia, $25.69 \pm 2.7$ years for those with severe preeclampsia, and $25.20 \pm 2.4$ years for those with eclampsia $(P=0.136)$. These ages are slightly different from those reported in other studies (in one study, for example, controls were aged $28.8 \pm 2.1$ years and preeclampsia patients $28.52 \pm 4.07$ years $[P=0.39]) .{ }^{12}$ Further, in our study, risk factors were reported in $58.00 \%$ of cases and a history of preeclampsia in a previous pregnancy in $2.12 \%$, whereas another study reported risk factors for preeclampsia in $91 \%$ of patients. ${ }^{11}$

After comparison with controls, oliguria was found in $10.56 \%$ of patients with HDP. This was comparable to another study, ${ }^{11}$ in which oliguria was found in $9.43 \%$ of women with HDP. In the present study, oliguria was found in $18.75 \%$ of severe preeclampsia cases and $20.00 \%$ of eclampsia cases and the difference was statistically significant $(P<0.001)$.

The most common manifestation in our study was edema, which is a very common symptom seen in $80 \%$ of normal pregnancies. ${ }^{8}$ The next most common manifestation was proteinuria. This may be due to glomerular involvement in the form of glomerular capillary endotheliosis, which results in reduced glomerular filtration rate and proteinuria.

It has been found, however, that hypertension and proteinuria may be absent in $10 \%-15 \%$ of patients who develop HELLP syndrome and in $38 \%$ of those who develop eclampsia. ${ }^{13,14}$ In our study, proteinuria of $\geq 300 \mathrm{mg} / 24$ hours was seen in $26.76 \%$ of cases and proteinuria of $\geq 2 \mathrm{~g} / 24$ hours was reported in $47.88 \%$ of cases. Just over one-quarter $(25.35 \%)$ of cases had urinary protein excretion of $3-5 \mathrm{~g} / 24$ hours.

The majority of patients in the eclampsia group were of low socioeconomic status $(73.37 \%)$. These patients were largely illiterate and deprived of antenatal care. In most patients with preeclampsia, the condition remains asymptomatic so the diagnosis of preeclampsia is often missed.

In another study, it was reported that proteinuria disappeared in all patients over an average time of 32.6 days

Table 4 Distribution of various maternal complications among study groups (\%)

\begin{tabular}{lllll}
\hline Maternal complication & $\begin{array}{l}\text { Control } \\
(\mathbf{n}=\mathbf{3 1})\end{array}$ & $\begin{array}{l}\text { Mild preeclampsia } \\
(\mathbf{n}=\mathbf{6 5})\end{array}$ & $\begin{array}{l}\text { Severe preeclampsia } \\
(\mathbf{n}=\mathbf{3 2})\end{array}$ & $\begin{array}{l}\text { Eclampsia } \\
(\mathbf{n}=\mathbf{4 5})\end{array}$ \\
\hline Acute renal failure & 0.00 & 0.00 & 3.13 & 0.00 \\
Abruption & 0.00 & 15.38 & 25.00 & 15.56 \\
Cerebrovascular accident & 0.00 & 0.00 & 0.00 & 2.22 \\
PPE & 0.00 & 12.50 & 27.27 & 14.29 \\
Postpartum hemorrhage & 3.22 & 9.23 & 12.50 & 11.10 \\
Pulmonary embolism & 0.00 & 0.00 & 0.00 & 2.22 \\
Chronic hypertension & 0.00 & 1.53 & 6.25 & 2.22 \\
Focal deficit & 0.00 & 0.00 & 0.00 & 2.22 \\
Death & 0.00 & 0.00 & 0.00 & 8.89 \\
\hline Abro
\end{tabular}

Abbreviation: PPE, post partum eclampsia. 
Table 5 Distribution of mode of delivery and fetal outcome

\begin{tabular}{|c|c|c|c|c|c|}
\hline Fetal outcome & $\begin{array}{l}\text { Control } \\
(n=31)\end{array}$ & $\begin{array}{l}\text { Mild preeclampsia } \\
(n=65)\end{array}$ & $\begin{array}{l}\text { Severe preeclampsia } \\
(n=32)\end{array}$ & $\begin{array}{l}\text { Eclampsia } \\
(n=45)\end{array}$ & $\begin{array}{l}\text { HDP group } \\
(n=142)\end{array}$ \\
\hline \multicolumn{6}{|l|}{ Mode of delivery } \\
\hline Normal & 21 (67.74\%) & 40 (6I.54\%) & $18(56.25 \%)$ & 29 (44.44\%) & 87 (6I.26\%) \\
\hline Instrumental & 0 & $\mathrm{I}(1.54 \%)$ & 0 & I $(2.22 \%)$ & $2(1.40 \%)$ \\
\hline LSCS & $10(32.26 \%)$ & 24 (36.92\%) & 14 (43.75\%) & $15(33.33 \%)$ & $63(37.32 \%)$ \\
\hline \multicolumn{6}{|l|}{ Fetal weight, g } \\
\hline$<1500 \mathrm{~g}$ & - & 3 (4.62\%) & I (3.13\%) & 5 (1I.20\%) & 9 (6.33\%) \\
\hline $1500-2499 \mathrm{~g}$ & 7 (22.60\%) & $33(50.76 \%)$ & $28(87.50 \%)$ & $10(22.30 \%)$ & 71 (50.00\%) \\
\hline$>2500 \mathrm{~g}$ & 24 (77.40\%) & 29 (44.62\%) & $3(9.40 \%)$ & $30(66.70 \%)$ & $62(43.70 \%)$ \\
\hline Stillborn & 0 & 5 (7.69\%) & 5 (I5.60\%) & 14 (31.10\%) & 24 (16.90\%) \\
\hline
\end{tabular}

Abbreviations: HDP, hypertensive disorders complicating pregnancy; LSCS, lower segment cesarean section.

(10-90 days postpartum) and, in another, that it resolved in 35.8 days (21-90 days postpartum). ${ }^{11,15}$ Similarly, in our study, proteinuria disappeared in an average of 32.6 days (10-90 days postpartum).

Clinical acute renal failure occurred in one patient (2.2\%), whereas in other studies the incidence of acute renal failure has varied from $4 \%$ to $23 \% .{ }^{16,17}$

Most central nervous system involvement was found in patients in the eclampsia group. Neurological abnormality was found in $42.22 \%$ of cases and $20.00 \%$ of patients complained of blurred vision and, following fundus examination, $13.30 \%$ of patients were found to have had abnormal fundoscopic changes. Arteriolar attenuation was the most common finding, present in $4.5 \%$ cases, and HELLP syndrome was reported in $2.8 \%$ cases. The incidence of HELLP syndrome is $2 \%-12 \%$ in preeclampsia. ${ }^{18,19}$

HELLP syndrome may develop in the antepartum as well as postpartum periods. In the postpartum period, the time of onset ranges from a few hours to 7 days, but the majority of patients develop HELLP syndrome within 48 hours. Conservative treatment is recommended in order to delay the time of delivery. ${ }^{18}$ In the present study, HELLP syndrome was observed in $3.07 \%$ of patients in the preeclampsia group and in $4.50 \%$ of patients in the eclampsia group. Prakash et al reported HELLP syndrome in $7.5 \%$ of cases of preeclampsia. However, the true incidence of this syndrome is not known because of the differences in diagnostic criteria. ${ }^{1}$
Hyperuricemia was found in $94 \%$ of patients with HDP in our study. In normal pregnancy, serum uric acid level decreases $(2.5-4.5 \mathrm{mg} / \mathrm{dL})$ due to plasma volume expansion. A mean serum uric acid level of more than $7.36 \pm 1.8 \mathrm{mg} / \mathrm{dL}$ is consistent with the diagnosis of preeclampsia and rising mean values of $8.36 \pm 1.8 \mathrm{mg} / \mathrm{dL}$ suggest more severe disease (severe preeclampsia). In our study, patients in the eclampsia group had a mean uric acid level of $6.6 \pm 2.0 \mathrm{mg} / \mathrm{dL}$, which was lower than that of patients in the preeclampsia group.

Serum creatinine and blood urea are important predictors for renal injury. In our study, levels of these predictors were found to be normal in the control group and raised in all the study groups. The highest values were found in the group with severe preeclampsia, suggesting the highest likelihood of kidney injury in this group.

Serum bilirubin is rarely increased in patients with preeclampsia, but when elevated, indirect fraction predominates suggesting hemolysis related elevation of bilirubin. A rise in serum bilirubin associated with increased serum LDH ( $>600 \mathrm{U} / \mathrm{L}$ ) is highly suggestive of HELLP syndrome. ${ }^{18}$

In our study, we observed an increase in serum bilirubin levels above the normal level for pregnancy $(1.2 \mathrm{mg} / \mathrm{dL}) .^{18}$ Serum bilirubin was raised in $57 \%$ of patients. Mean values of serum bilirubin in mild preeclampsia, severe preeclampsia, and eclampsia cases were $1.31 \pm 0.8 \mathrm{mg} / \mathrm{dL}, 1.89 \pm 1.2 \mathrm{mg} / \mathrm{dL}$, and $1.86 \pm 0.8 \mathrm{mg} / \mathrm{dL}$, respectively, and this difference was

Table 6 Neonatal outcome

\begin{tabular}{|c|c|c|c|c|c|}
\hline Group & $\begin{array}{l}\text { Control } \\
(n=31)\end{array}$ & $\begin{array}{l}\text { Mild preeclampsia } \\
(\mathrm{n}=60)\end{array}$ & $\begin{array}{l}\text { Severe Preeclampsia } \\
(n=27)\end{array}$ & $\begin{array}{l}\text { Eclampsia } \\
(n=31)\end{array}$ & $\begin{array}{l}\text { Total } \\
(n=1 \mid 8)\end{array}$ \\
\hline Apgar score $<7$ & $2(6.45 \%)$ & 7 (II.67\%) & $2(7.40 \%)$ & II (35.48\%) & $20(16.90 \%)$ \\
\hline Apgar score $>7$ & 29 (93.55\%) & $53(88.30 \%)$ & $25(92.60 \%)$ & $20(64.52 \%)$ & $98(83.05 \%)$ \\
\hline Required resuscitation & $2(6.50 \%)$ & II (I8.40\%) & II (40.75\%) & $12(38.70 \%)$ & II 8 (28.80\%) \\
\hline NICU admission & $2(6.50 \%)$ & $8(13.40 \%)$ & $7(25.90 \%)$ & $9(29.10 \%)$ & $24(20.35 \%)$ \\
\hline Neonatal death & - & I (I.70\%) & I (3.70\%) & 3 (9.70\%) & 5 (4.23\%) \\
\hline
\end{tabular}

Abbreviation: $\mathrm{NICU}$, neonatal intensive care unit. 
statistically significant $(P<0.001)$. Liver enzymes (serum glutamic oxaloacetic transaminase, serum alkaline phosphatase, and serum glutamate pyruvate transaminase) were significantly increased in all HDP groups $(P<0.001)$. Rise in serum LDH level was observed in all study groups, but more so in the severe preeclampsia group and the difference was statistically significant $(P<0.001)$.

Fetal and neonatal outcomes were measured in terms of prevalence of intrauterine growth restriction, low birth weight, Apgar score, the need for resuscitation and/or admission to a neonatal intensive care unit, and stillbirths and neonatal deaths. Incidence of intrauterine growth restriction was found in $15.50 \%$ of births, low birth weight in $56.30 \%$, stillbirths in $16.90 \%$, and $4.23 \%$ of neonates overall died. Neonatal death occurred most in the eclampsia group, affecting $9.7 \%$ of births in that group. Yadav et al reported preterm deliveries in $28.8 \%$, stillbirths in $4.8 \%$, and $14.8 \%$ overall perinatal mortality. ${ }^{20}$ In our study, $16.9 \%$ of neonates born to women in the HDP groups had an Apgar score $<7$ compared with $6.45 \%$ in the control group. Further, $28.8 \%$ of neonates born to women in the HDP groups required resuscitation and $20.3 \%$ required hospital admission compared with only $6.5 \%$ in the control group. Perloff et al reported that perinatal mortality in preeclampsia is five times higher than normal perinatal mortality and this increases to $20 \%$ in infants of women with eclampsia. ${ }^{21}$

Maternal outcome was measured in terms of various maternal complications, mode of delivery, and maternal mortality. Most (61.26\%) women with HDP had normal vaginal deliveries compared with $67.74 \%$ of women in the control group. No women in the control group had an instrumental delivery compared with $1.4 \%$ of women in the HDP groups. Operative intervention was more common with hypertensive disorders, with lower segment cesarean sections undertaken in $37.32 \%$ of HDP patients versus $32.26 \%$ of control subjects. Overall maternal mortality was $2.8 \%$. The highest maternal mortality was observed in the eclampsia group (8.89\%), which contrasts with the $17 \%-18 \%$ rate reported in patients with eclampsia in two other studies. ${ }^{22,23}$ In our study, the lower incidence of maternal mortality could be due to the increased number of hospital deliveries that occurred and improved antenatal care. Major causes of death in preeclampsia and eclampsia are neurological complications, such as intracerebral hemorrhage and cerebral edema. ${ }^{24}$

\section{Conclusion}

Out of 1850 pregnant women screened in a one year period, HDP was reported in $8.05 \%$ and acute renal failure occurred in one case. Mortality was highest in the eclampsia group, possibly because of the severity of the disease itself and the associated systemic complications. A higher frequency of adverse fetal outcomes was found in hypertensive pregnant women than in normotensive pregnant women. Overall maternal mortality was lower in our study than in previous Indian studies, which might be due to the increased number of prompt deliveries, with magnesium sulfate therapy and good intensive care. However, there was a higher incidence of stillbirth (16.9\%) in our study compared to in previous studies. Hence, there is a need to strengthen neonatal intensive care units and to increase patients' awareness of the importance of antenatal checkups during early pregnancy to prevent complications. Good intensive care in addition to labor monitoring and expeditious delivery is required for better outcomes in cases of severe preeclampsia and eclampsia.

\section{Disclosure}

The authors declare no conflicts of interest in this work.

\section{References}

1. Prakash J, Pandey LK, Singh AK, Kar B. Hypertension in pregnancy: hospital based study. J Assoc Physicians India. 2006;54:273-278.

2. Sibai BM, Mercer B, Sarinoglu C. Severe preeclampsia in the second trimester: recurrence risk and long-term prognosis. Am J Obset Gynecol. 1991;165(5 Pt 1):1408-1412.

3. Barton JR, O’brien JM, Bergauer NK, Jacques DL, Sibai BM. Mild gestational hypertension remote from term: progression and outcome. Am J Obstet Gynecol. 2001;184(5):979-983.

4. Sibai BM, Sarinoglu C, Mercer BM. Eclampsia. VII. Pregnancy outcome after eclampsia and long-term prognosis. Am J Obstet Gynecol. 1992;166(6 Pt 1):1757-1761; discussion 1761-1763.

5. Maynard SE, Min JY, Merchan J, et al. Excess placental soluble fmslike tyrosine kinase 1 (sFlt1) may contribute to endothelial dysfunction, hypertension, and proteinuria in preeclampsia. J Clin Invest. 2003; 111(5):649-658.

6. Matthys LA, Coppage KH, Lambers DS, Barton JR, Sibai BM. Delayed postpartum preeclampsia: an experience of 151 cases. Am J Obstet Gynecol. 2004;190(5):1464-1466.

7. Pennington KA, Schlitt JM, Jackson DL, Schulz LC, Schust DJ. Preeclampsia: multiple approaches for a multifactorial disease. Dis Model Mech. 2012;5(1):9-18.

8. Report of the National High Blood Pressure Education Program Working Group on High Blood Pressure in Pregnancy. Am J Obstet Gynecol. 2000;183(1):S1-S22.

9. Kumar N, Gupta N, Kishore, J. Kuppuswamy's socioeconomic scale: updating income ranges for the year 2012. Indian J Public Health. 2012;56:103-104

10. Menon MK. The evolution of the treatment of eclampsia. J Obstet Gynaecol Br Commonw. 1961;68:417-426.

11. Prakash J, Vohra R, Pandey LK, Niwas SS, Behura SK, Singh U. Spectrum of kidney diseases in patients with preeclampsia-eclampsia. J Assoc Physicians India. 2010;58:543-546.

12. D’Anna R, Baviera G, Giordano D, Todarello G, Corrado F, Buemi M. Second trimester neutrophil gelatinase-associated lipocalin as a potential prediagnostic marker of preeclampsia. Acta Obstet Gynecol Scand. 2008;87(12):1370-1373.

13. Sibai BM. Diagnosis, controversies, and management of the syndrome of hemolysis, elevated liver enzymes, and low platelet count. Obstet Gynecol. 2004;103(5 Pt 1):981-991. 
14. Douglas KA, Redman CW. Eclampsia in the United Kingdom. BMJ. 1994;309(6966):1395-1400.

15. Gärtner HV, Sammoun A, Wehrmann M, Grossmann T, Junghans R, Weihing C. Preeclamptic nephropathy - an endothelial lesion. A morphological study with a review of the literature. Eur J Obstet Gynecol Reprod Biol. 1998;77(1):11-27.

16. Mjahed K, Alaoui SY, Barrou L. Acute renal failure during eclampsia: incidence risks factors and outcome in intensive care unit. Ren Fail. 2004;26(3):215-221.

17. Peng DZ. Acute renal failure in severe pregnancy induced hypertension: a report of 19 cases. Zhonghua Fu Chan Ke Za Zhi. 1993;28(5): 281-283, 314. Chinese.

18. Barton JR, Sibai BM. HELLP and the liver diseases of pre-eclampsia. Clin Liver Dis. 1999;3:31-48.

19. Conrad KP, Lindheimer MD. Renal and cardiovascular alterations. In: Lindheimer MD, Roberts JM, Cunningham FG, editors. Chesley's Hypertensive Disorders in Pregnancy, 2nd ed. Stamford, CT: Appleton and Lange; 1999:263-326.
20. Yadav S, Saxena U, Yadav R, Gupta S. Hypertensive disorders of pregnancy and maternal and foetal outcome: a case controlled study. J Indian Med Assoc. 1997;95(10):548-551.

21. Perloff D. Hypertension and pregnancy-related hypertension. Cardiol Clin. 1998;16(1):79-101.

22. Aali BS, Ghafoorian J, Mohamad-Alizadeh S. Severe preeclampsia and eclampsia in Kerman, Iran: complications and outcomes. Med Sci Monit. 2004;10(4):CR163-CR167.

23. Sibai BM, Ramadan MK. Acute renal failure in pregnancies complicated by hemolysis, elevated liver enzymes, and low platelets. Am J Obstet Gynecol. 1993;168(6 Pt 1):1682-1687; discussion 1687-1690.

24. Rodríguez González D, Godina Gallardo M, Hernández Chávez A, Ramírez García A, Hernández Camarena R. Severe pre-eclampsia, HELLP syndrome and renal failure. Gynecol Obstet Mex. 1998;66:4851. Spanish.
International Journal of Women's Health

\section{Publish your work in this journal}

The International Journal of Women's Health is an international, peerreviewed open-access journal publishing original research, reports, editorials, reviews and commentaries on all aspects of women's healthcare including gynecology, obstetrics, and breast cancer. The manuscript management system is completely online and includes

\section{Dovepress}

a very quick and fair peer-review system, which is all easy to use Visit http://www.dovepress.com/testimonials.php to read real quotes from published authors. 